\title{
Yamamoto new scalp acupuncture: its applications and results in painful conditions. Systematic review
}

\author{
Nova crâniopuntura de Yamamoto, suas aplicações e resultados em condições dolorosas. \\ Revisão sistemática
}

Dérrick Partrick Artioli ${ }^{1}$ Marcus Vinícius Gonçalves Torres Azevedo' ${ }^{1}$, Gladson Ricardo Flor Bertolini²

DOI 10.5935/2595-0118.20180035

\section{ABSTRACT}

BACKGROUND AND OBJECTIVES: The new Yamamoto craniopuncture is consistently linked to systemic acupuncture or erroneously described as the Chinese craniopuncture (Chiao Shu $\mathrm{Fa}$ ). Its use is mostly described in neurological conditions (i.e., stroke). However, there is no single study reviewing its capacity for analgesic effects compared to other groups, which application points are the most used and the quality of the research developed.

CONTENTS: For this analysis, the databases Pubmed, Pedro database, Scielo and LILACS were accessed searching for clinical trials with the following keywords: Craniopuncture; Scalp Acupuncture; Yamamoto New Scalp Acupuncture; Pain (English, Portuguese and Spanish). The AND Boolean index was used between the selected keyword and pain (e.g., Scalp Acupuncture AND pain). The only three selected studies were evaluated by the Jadad score for clinical trials, and most of them have been considered of poor methodological quality. The Yamamoto New Scalp Acupuncture was superior to the groups compared (placebo and control), similar in effects to other interventions (systemic acupuncture and $\mathrm{Ai} \mathrm{Chi}$ ) and the basic points (A-I) were the most used.

CONCLUSION: At presents, the Yamamoto New Scalp Acupuncture present itself as a promising alternative therapy, but further studies of higher methodological quality are needed for further conclusions.

Keywords: Acupuncture, Pain, Physical therapy modalities, Physical therapy specialty, Rehabilitation.

\footnotetext{
1. Centro Universitário Lusíada, Santos, SP, Brasil.

2. Universidade Estadual do Oeste do Paraná, Cascavel, PR, Brasil.

Submitted in December 04, 2017.

Accepted for publication in April 04, 2018.

Conflict of interests: none - Sponsoring sources: none.

Endereço para correspondência:

Rua Universitária, 2069 - Jardim Universitário

85819-110 Cascavel, PR, Brasil.

E-mail: gladsonricardo@gmail.com

(C) Sociedade Brasileira para o Estudo da Dor
}

\section{RESUMO}

JUSTIFICATIVA E OBJETIVOS: A nova crâniopuntura de Yamamoto é constantemente vinculada com acupuntura sistêmica ou descrita erroneamente como crâniopuntura chinesa (Chiao Shu Fa). Há maior descrição de seu uso em condiçôes neurológicas (ex.: acidente vascular encefálico). No entanto, até o momento, nenhum estudo revisou isoladamente a capacidade de seus efeitos analgésicos comparados a outros grupos, quais pontos de aplicação são os mais utilizados e a qualidade das pesquisas desenvolvidas.

CONTEÚDO: Para tal análise, as bases de dados Pubmed, Pedro database, Scielo e LILACS foram acessadas em busca de ensaios clínicos com as seguintes palavras chaves: Craniopuncture; Scalp Acupuncture; Yamamoto New Scalp Acupuncture; Pain (Inglês, Português e Espanhol). O índice booleano $A N D$ foi utilizado entre a palavra-chave selecionada e dor (p. ex.: Scalp Acupuncture AND pain). Os únicos três estudos selecionados, foram avaliados pelo escore de Jadad para ensaios clínicos, caracterizando-os em sua maioria, como de baixa qualidade metodológica. A Nova Crâniopuntura de Yamamoto mostrou-se superior aos grupos comparados (placebo e controle), efeito semelhante a outras intervençóes (acupuntura sistêmica e Ai Chi) e os pontos básicos (A-I) foram os mais utilizados.

CONCLUSÁO: No momento, a nova crâniopuntura de Yamamoto apresenta-se como uma terapia alternativa promissora, mas que carece de estudos de alta qualidade metodológica para maiores conclusôes.

Descritores: Acupuntura, Dor, Fisioterapia, Modalidades de fisioterapia, Reabilitação.

\section{INTRODUCTION}

In general, regardless the cause, pain is something that all people will experience at some moment in life, whether it is an isolated acute episode or chronic (lasting more than three months). For centuries, systemic acupuncture has been widely used as a treatment for musculoskeletal conditions as an adjuvant in the treatment of pain. Using disposable needles, specific points (based on channels and meridians) are activated providing a neuromodulatory effect on parts of the central nervous system (CNS), peripheral and neurotransmitters. This technique is part of the guidelines that recommend alternatives to manage painful pictures. It does not present complications regarding drug interactions, feasible in any age 
group, and it is a low-cost resource. In addition to the traditional use that involves the combination of points throughout several parts of the body, acupuncture also has some derivations, generating isolated points of treatment (microsystems) ${ }^{1}$. If the craniopuncture microsystem is mistakenly listed as part of the classic systemic acupuncture, the differentiation between the Japanese practice (Yamamoto New Scalp Acupuncture - YNSA) and the Chinese (Chiao Shun Fa) is seldom discriminated and analyzed separately. Although being both on the head, the anatomic interpretation of application sites, principles and even the way in which the needles are inserted, differ. In the YNSA, the majority of its points (basic) are on the patient's forehead, and in the Chinese craniopuncture, the application site is on the lateral region of the skull (frontotemporal). In the Japanese technique, only the initial millimeters of the tip of the needle is inserted, whereas, in Chiao Shun $F$ a, about $2 / 3$ of the needle penetrates the epidermis parallelly. Although both are described for the treatment of multiple diagnoses, especially neurological (stroke), there is a better aggregation of the YNSA analgesic effect in relation to the Chinese procedure. Therefore, a professional who knows one of these craniopuncture procedures does not necessarily master the other ${ }^{2}$.

YNSA was introduced to the world at the beginning of the 1970s as one microsystem in which the stimulation of points on the skull creates an effect on other parts of the body, collaborating to the treatment of diseases ${ }^{3}$. The theory involves diagnostic regions and therapeutic attribution. YNSA requires a previous diagnosis to determine the sites to be chosen. This is done on the application site (Ashi points on the skull) or other sites, as, for example, painful points on the musculature lateral to the neck, abdominal wall or using the acupuncture point located radially to the metacarpus (IG4). The treatment zones are all located on the head and divided into basic points, brain sensorial points, $\mathrm{Y}$ points and scalp pairs $^{4}$ (Figure 1).

As already described, everyone will eventually experience a painful situation. Therefore, guidelines, protocols, recommendations, and guides to the therapeutic approach to pain have been developed ${ }^{1,5,6}$. Among these, acupuncture is one of the recommended to manage and handle painful pictures ${ }^{1}$. Since YNSA is pointed as a complementary alternative therapy to this condition, it is necessary to analyze the outcomes that corroborate such statement.

Lee et $\mathrm{al}^{2}{ }^{2}$ conducted a systematic review and meta-analysis of the craniopuncture in stroke, but up to now, there is one single review of the studies related to YNSA and musculoskeletal pain conditions. In other words, comparisons of the selected points and the effect of this technique with another intervention have not yet been conducted, not even the methodologic quality of these research has been analyzed.

The objectives of this study were: (1) to analyze the results of clinical trials with control group regarding pain using the YNSA; (2) to determine the most selected points for each situation, and (3) the methodologic quality of the studies (Jadad et al. scores) ${ }^{7}$.

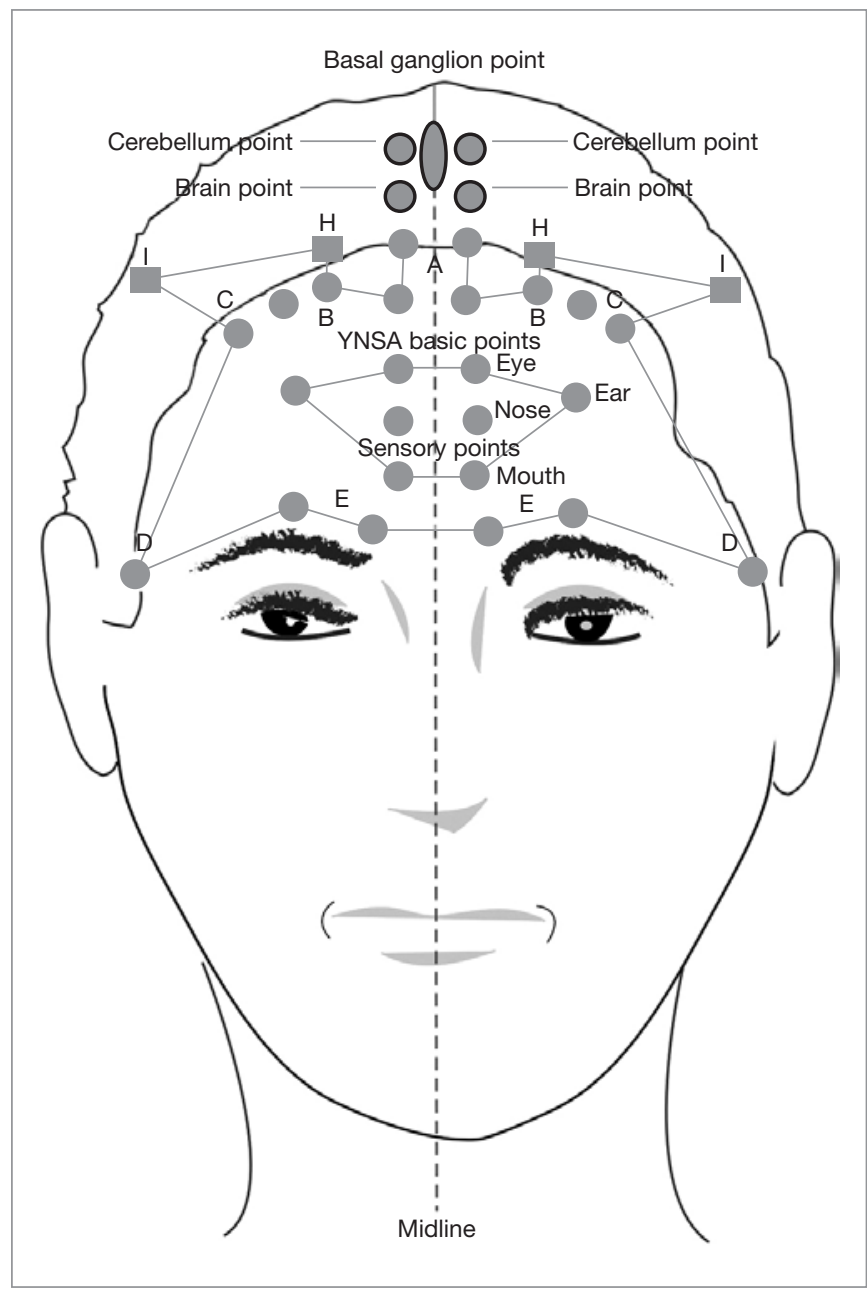

Figure 1. Basic points of Yamamoto new scalp acupuncture $\mathrm{A}-\mathrm{H}$, brain and sensorial. $\mathrm{A}=$ cervical spine; $\mathrm{B}=$ shoulder (shoulder girdle complex); $C=$ shoulder joint and upper extremity; $D=$ lumbar spine and low extremity; $\mathrm{E}=$ chest; $\mathrm{F}=$ ischiatic nerve; $\mathrm{G}=$ knee; $\mathrm{H}=$ extra lumbar point ${ }^{3}$.

\section{CONTENTS}

The PubMed, Pedro, Scielo, and LILACS database were used. The following keywords were used in the search: Craniopuncture; Scalp Acupuncture; Yamamoto New Scalp Acupuncture; Pain (English, Portuguese and Spanish). The Boolean index $A N D$ was used between the selected keyword and pain (i.e., Scalp Acupuncture AND pain), directing to pain pictures and eliminating other variables (motor, sensitive analysis, and function). These keywords should be found in the title or abstract of the article for inclusion. Moreover, "Clinical Trials" were one of the applied filters to eliminate other methodologies that did not include comparative characteristics of data among groups and needed to have pain as one of the analyzed variables. Other exclusion criteria were experiments with animals, Chinese craniopuncture, studies with injuries in the central neurological system (i.e., stroke and Parkinson disease), and when they were repeated in the database the analysis was performed in only one of them. The studies that met the inclusion criteria were evaluated according to the Jadad et al. scale ${ }^{7}$ for clinical trials, by two 
professionals with experience in musculoskeletal physiotherapy, without eliminating the study because of the score, that is, only indicating the methodologic quality of the article. The software Statistica 7 was used to analyze the data. Table 1 shows the quantitative data of the search.

The analyzed studies indicate superior outcome to the control group with the YNSA; the basic points were the most used and the methodologic quality was quantified as low (poor) in its majority.

Table 2 summarizes the results of the selected clinical trials in decreasing order, that is, the higher the score indicated by the Jadad et al. score ${ }^{7}$, better the methodologic quality of the study. The outcome of the analyzed studies shows the beneficial and superior effects to the control group when using the YNSA. Only the study of Rezvani et al. ${ }^{8}$ with people with headache showed similarity and not favorable results in comparison to the control intervention. However, the counter intervention was the systemic acupuncture, which is cited as one of the ways to manage pain ${ }^{10}$. That is, the results similar to this method cannot be considered bad since the YNSA is pointed as one microsystem of acupuncture and that perhaps is better tolerated because it requires a lesser number of needles ${ }^{8}$.

The population analyzed by two other studies was patients with back pain. The Hasegawa et al. ${ }^{4}$ study, which got the best methodologic score among the analyzed studies, used a control group

Table 1. Search results in the database

\begin{tabular}{lcccc}
\hline Database & Found & Repeated & Excluded & Final $^{*}$ \\
\hline Pubmed & 11 & 2 & 7 & 2 \\
Pedro & 11 & 2 & 7 & $2^{* *}$ \\
Scielo & 9 & 1 & 7 & 1 \\
LILACS & 13 & 1 & 11 & $1^{* *}$ \\
Total & 44 & 6 & 32 & $6-3=3$ \\
\hline${ }^{*}$ - Selected and analyzed studies; ${ }^{* *}$ - Repeated in another database.
\end{tabular}

(placebo) very similar to the intervention group. Both groups performed the same procedure, placing the application mandril in contact with the skin, and using the same way to select the points, but without inserting the needle. Clarifying the actual effect of the YNSA in improving the evaluation parameters compared to the control group and with only 5 sessions of $20 \mathrm{~min}$ utes. The second study involving back pain also showed to be effective regarding the reduction of pain in relation to the control group. However, the use of $A i C h i$ was as good as the YNSA? Accrediting the reduction of pain to the use of the YNSA is probably due to the activation of the A-delta and $\mathrm{C}$ afferent fibers that generate information in the spinal cord and leads to the production of dynorphin and enkephalin. These afferent stimulations travel to the CNS releasing neurotransmitters such as serotonin, dopamine, and norepinephrine that when reaching the hypothalamus and the pituitary gland, release endorphins and acetylcholine, reducing pain through the descending suppressor system ${ }^{9,10}$.

In the selection of the basic points (A - I), which were the most used in the described studies, the most common way to find such points is determining the most painful site next to the area designated as the point function. This strategy seems to work well to minimize the anatomical differences among individuals ${ }^{3}$. However, there is still the possibility of other diagnostic criteria to select such points, as the access to points in the cervical region, on the hands (IG4) and abdomen, as Rezvani et al. ${ }^{8}$ did. However, this study did not make it clear if the needles had been inserted unilaterally or bilaterally in the selected points. On the other hand, Hasegawa et al. ${ }^{4}$ applied them bilaterally and Camilotti et al. ${ }^{9}$ unilaterally. Moreover, this makes it difficult to determine any influence in the effect due to the divergence between the authors regarding the side of the application. Some authors advocate the insertion of the needles on the most painful homolateral side of the IG4 point (systemic acupuncture) ${ }^{11}$. However, in the light of this, the variability of the diagnostic types pos-

Table 2. Characteristics of the analyzed clinical trials

\begin{tabular}{|c|c|c|c|c|c|c|c|}
\hline Authors & Objectives & Counter intervention & Population & YNSA points & Duration and sessions & Jadad & Results \\
\hline $\begin{array}{l}\text { Hasegawa } \\
\text { et al. }{ }^{4}\end{array}$ & $\begin{array}{l}\text { The effectiveness } \\
\text { of the YNSA in pain } \\
\text { (VAS), use of anal- } \\
\text { gesics (frequency), } \\
\text { functional capaci- } \\
\text { ty (Roland-Morris } \\
\text { Questionnaire) and } \\
\text { quality of life (SF-36) }\end{array}$ & Placebo & $\begin{array}{l}\text { Non-specific } \\
\text { acute back } \\
\text { pain } \\
80 \text { patients: IG } \\
(40) \text { and CG } \\
(40)\end{array}$ & $\begin{array}{l}\text { Basic: D; D1-D6; } \\
\text { H; I. } \\
\text { Y: Bladder; Kid- } \\
\text { ney; Liver } \\
\text { PD (cervical): } \\
\text { Kidney; Bladder; } \\
\text { Liver }\end{array}$ & $20 \mathrm{~min} ; 5$ sessions & 3 & $\begin{array}{l}\text { Superior } \\
\text { to the } C G \\
(p<0.05)\end{array}$ \\
\hline $\begin{array}{l}\text { Rezvani et } \\
\text { al. }^{8}\end{array}$ & $\begin{array}{l}\text { Therapeutic effect } \\
\text { in the prophylaxis } \\
\text { and treatment of } \\
\text { headache (VAS and } \\
\text { MTAQ) }\end{array}$ & $\begin{array}{l}\text { Systemic Chinese } \\
\text { Traditional Acu- } \\
\text { puncture (CTA) }\end{array}$ & $\begin{array}{l}80 \text { patients } \\
\text { with headache: } \\
40 \text { CTA (CG) } \\
\text { and } 40 \text { YNSA }\end{array}$ & $\begin{array}{l}\text { Basic: A1-7; C: } \\
\text { M1-3; } \\
\text { Y: not described; } \\
\text { PD: hands, cervi- } \\
\text { cal and abdomen }\end{array}$ & $30 \mathrm{~min} ; 18$ sessions & 2 & $\begin{array}{l}\text { Similar to } \\
\text { the CG } \\
(p>0.05)\end{array}$ \\
\hline $\begin{array}{l}\text { Camilotti } \\
\text { et al. }{ }^{9}\end{array}$ & $\begin{array}{l}\text { Effectiveness of } \\
\text { YNSA and } \mathrm{Ai} \text { Chi } \\
\text { regarding pain (VAS) } \\
\text { and functional ca- } \\
\text { pacity (Owestry) }\end{array}$ & Ai Chi and CG & $\begin{array}{l}\text { Chronic back } \\
\text { pain } \\
44 \text { patients: Ai } \\
\text { Chi (15); YNSA } \\
\text { (15); CG (14) }\end{array}$ & Basic: D; D1-D5. & $\begin{array}{l}20 \mathrm{~min} ; 10 \text { sessions } \\
(2 / \mathrm{wk})\end{array}$ & 1 & $\begin{array}{l}\text { Superior } \\
\text { to the CG } \\
\text { and similar } \\
\text { to } \mathrm{Ai} C h i \\
(\mathrm{p}<0.05)\end{array}$ \\
\hline
\end{tabular}

YNSA = Yamamoto New Scalp Acupuncture; VAS = visual analog scale; CG = control group; IG = intervention group; $Y=$ ipsilon; $C=$ brain; PD = diagnostic points wk = week; MTAQ = Migraine Therapy Assessment Questionnaire. 
sibly contributes to different decision making without having a method that is considered superior to the other.

The YNSA, unlike other strategies of care, requires smaller physical space for its application (the patient can remain seated) and it uses low-cost input as described by Hasegawa et al. ${ }^{4}$. Moreover, the effects can be noticed within few sessions and even immediate effects have been described ${ }^{3,4}$. The application duration is not long (20-30 minutes, with periodic stimulation) which does not greatly interfere with other procedures, making it easy to be used in hospital wards and outpatient settings, specialized clinics, basic care units, public rehab centers or private clinics. Although promising, the YNSA lacks the development of high methodologic quality research to determine its level of contribution to the treatment of pain. Since it was not superior to the systemic acupuncture in the Rezvani et al. ${ }^{8}$ study (providing the same benefits to the patient) and in the other two studies where it showed to be an advantageous method, the methodologic quality of one of them was bad (Jadad $=1$ ).

As limitations of the present study, we can indicate the scarcity of clinical trials in the western database analyzed and the inclusion of eastern database could get a bigger number of studies for analysis. In this attempt, the Japanese National Institute of Informatics Scholarly and Academic Information Navigator (CiNii) was accessed. However, the language (Japanese) made it impossible for the authors to analyze the studies, some involved animals or were not freely available in full. Likewise, German ${ }^{12}$ and Chinese studies could not be analyzed due to the authors' limitations. Nevertheless, other studies ${ }^{11,13,14}$ were excluded because they did not meet the assigned methodology, such as not using a control group or using the Chinese Craniopuncture ${ }^{15-19}$.

\section{CONCLUSION}

The YNSA seems to be a promising technique that has beneficial effects in painful conditions in the lumbar region, especially non-specific acute back pain, being the (A-I) basic points the most used with results in few sessions (immediate or 5 to 18 sessions), with a satisfactory application duration (20-30 minutes) and low cost. It can be considered an alternative or complementary therapy with perspectives of good results, but it lacks more scientific base with studies of high methodologic quality.

\section{REFERENCES}

1. Kopf A, Patel NB. Guia para o Tratamento da Dor em Contextos de Poucos Recursos. viii (2010).

2. Lee SJ, Shin BC, Lee MS, Han CH, Kim JI. Scalp acupuncture for stroke recovery: a systematic review and meta-analysis of randomized controlled trials. Eur J Integr Med. 2013;5(2):87-99.

3. Yamamoto T, Yamamoto HY. Yamamoto new scalp accupuncture.pdf. (2007).

4. Hasegawa TM, Baptista AS, de Souza MC, Yoshizumi AM, Natour J. Acupuncture for acute non-specific low back pain: a randomised, controlled, double-blind, placebo trial. Acupunct Med. 2014;32(2):109-15.

5. Dor Crônica - Protocolo Clínico e Diretrizes Terapêuticas. Portaria SAS/MAS N 1083, 02 outubro 2012 - Retificada em 27 novembro de 2015.

6. International Association for the Study of Pain Task Force on Wait-Times. 1-5

7. Jadad AR, Moore RA, Carroll D, Jenkinson C, Reynolds DJ, Gavaghan DJ, et al. Assessing the quality of reports of randomized clinical trials: is blinding necessary? Control Clin Trials. 1996;17(1):1-12.

8. Rezvani M, Yaraghi A, Mohseni M, Fathimoghadam F. Efficacy of Yamamoto new scalp acupuncture versus Traditional Chinese acupuncture for migraine treatment. J Altern Complement Med. 2014;20(5):371-4.

9. Camilotti BM, Leite N, Alberti D, Francisco IA, Israel VL. Effects of Ai Ch and Yamamoto new scalp acupuncture on chronic low back pain. Fisioter Mov. 2015;28(4):723-30.

10. Gosling AP. Mecanismos de ação e efeitos da fisioterapia no tratamento da dor. Rev Dor. 2013;13(1):65-70.

11. Silva FB, Sacomani DG, Fregonesi CE, Masselli MR, Oliveira DL, Camargo MR. Efeito da craniopuntura na qualidade de vida e melhora da dor crônica. Arq Ciências Saúde UNIPAR. 2009;13(2):105-12.

12. Ogal HP, Hafer J, Ogal M, Krumholz W, Herget HF, Hempelmann G. [Variations of pain in the treatment of one classical acupuncture-point one point of Yamamoto's new scalp acupuncture]. Anaesthesiol Intensivmed Notfallmed Schmersther. 2002;37(6):326-32. German.

13. Correia LM, Alberti D, Lopes SS. Evaluation of chronic head and neck myofascial pain control with Yamamoto New Scalp Acupuncture in eight weeks follow-up period. Rev Dor. 2015;16(2):81-5.

14. Silva L, Taxoto AN, Montalvão EM, Marques AP, Alfredo PP. Efeitos da craniopuntura de Yamamoto na osteoartrite de joelho: estudo de caso Fisioter Pesq. 2011;18(3):287-91.

15. Chen CC, Yang CC, Hu CC, Shih HN. Chang YH, Hsieh PH. Acupuncture for pain relief after total knee arthroplasty: a randomized controlled trial. Reg Anesth Pain Med. 2015;40(1):31-6

16. Collazo CE, Muńoz Reina MD. Craneopuntura y acupuntura en el tratamiento de pacientes con fibromialgia. Estudio prospectivo aleatorizado. Rev Int Acupunt. 2013;7(1):6-11

17. He BM, Li WS, Li WY. [Effect of previous analgesia of scalp acupuncture on postoperative epidural morphine analgesia in the patient of intestinal cancer]. Zhongguo Zhen Jiu. 2007;27(5):369-71. Chinese.

18. Collazo E, Muńoz Reina MD, Aragonés MA, Gómez F. de la medicina tradicional china en el alivio del dolor y mejora de la calidad de vida en pacientes con fibromialgia. Rev Int Acupunt. 2014;121-8.

19. Bo QX, Zhang JX. [Observation on therapeutic effect of scalp acupuncture analgesia on labor]. Zhongguo Zhen Jiu. 2006;26(9):659-61. Chinese. 